\title{
EFFECT OF OMEGA-3 FATTY ACID IN THE HEALING PROCESS OF COLONIC ANASTOMOSIS IN RATS
}

\author{
Efeito do ácido graxo ômega-3 na cicatrização de anastomose colônica em ratos
}

Tiago Jacometo Coelho de CASTILHO', Antônio Carlos Ligocki CAMPOS1, Eneri Vieira de Souza Leite MELLO²

From the 'Programa de Pós-Graduação em Clínica Cirúrgica, Setor de Ciências da Saúde, Universidade Federal do Paraná, Curitiba, PR and 'Laboratório de Ciências Morfofisiológicas, Departamento de Ciências Morfofisiológicas, Universidade Estadual de Maringá, Maringá, PR ('Postgraduate Program in Surgery, Health Sciences Sector, Paraná Federal University of Paraná, Curitiba, PR and 'Laboratory of Morphophysiological Science, Department of Morphophysiological Science, State University of Maringá, Maringá, PR), Brazil.

HEADINGS - Omega-3. Wound healing. Colonic anastomosis. Rats.
ABSTRACT - Background: The use of long-chain polyunsaturated fatty acids has been studied in the context of healing and tissue regeneration mainly due to its anti-inflammatory, immunoregulatory and antioncogenic properties. Previous studies have demonstrated beneficial effects with the use of enteral immunonutrition containing various farmaconutrients such as L-arginine, omega-3, trace elements, but the individual action of each component in the healing of colonic anastomosis remains unclear. Aim: To evaluate the influence of preoperative supplementation with omega- 3 fatty acids on the healing of colonic anastomoses of well-nourished rats. Methods: Forty Wistar adult male rats, weighing $234.4 \pm 22.3 \mathrm{~g}$ were used. The animals were divided into two groups: the control group received for seven days olive oil rich in omega-9 oil through an orogastric tube, while the study group received isocaloric and isovolumetric omega-3 emulsion at a dose of $100 \mathrm{mg} / \mathrm{kg} /$ day, also for seven days. Both groups were submitted to two colotomies followed by anastomosis, in the right and left colon, respectively. Parameters evaluated included changes in body weight, anastomotic complications and mortality, as well as maximum tensile strength by using a tensiometer and collagen densitometry at the anastomotic site. Results: There were no differences in body weight or mortality and morbidity between groups. The value of the maximum tensile strength of the control group was $1.9 \pm 0.3 \mathrm{~N}$ and the study group $1.7 \pm 0.2, p=0.357$. There was, however, a larger amount of type I collagen deposition in the study group $(p=0.0126)$. The collagen maturation índex was $1.74 \pm 0.71$ in the control group and $1.67 \pm 0.5$ in the study group; $p=0,719$ ). Conclusions: Preoperative supplementation of omega- 3 fatty acid in rats is associated with increased collagen deposition of type I fibers in colonic anastomoses on the $5^{\text {th }}$ postoperative day. No differences were observed in the tensile strength or collagen maturation index.

\section{Correspondence:}

Tiago Jacometo Coelho de Castilho

E-mail: ticastilho@yahoo.com.br

Financial source: Conselho Nacional de Pesquisa (CNPQ)

Conflicts of interest: none

Received for publication: 30/04/2015 Accepted for publication: 20/08/2015

DESCRITORES: Omega-3. Cicatrização de feridas. Anastomose colônica. Ratos.
RESUMO - Racional: O uso de ácidos graxos poliinsaturados de cadeia longa tem sido estudado no contexto de cicatrização e regeneração do tecido, principalmente devido a suas propriedades imunorreguladoras, antioncogênicas e anti-inflamatórias. Estudos anteriores demonstraram efeitos benéficos com o uso de imunonutrição enteral contendo vários farmaconutrientes (L-arginina, ômega-3, oligoelementos), mas a ação individual de cada componente na cicatrização de anastomose colônica permanece incerto. Objetivo: Avaliar a influência da suplementação no pré-operatório com ácidos graxos ômega-3 na cicatrização de anastomoses colônicas de ratos eutróficos. Método: Quarenta ratos Wistar, machos adultos, pesando $234,4 \pm 22,3 \mathrm{~g}$ foram divididos em dois grupos: grupo controle recebeu a suplementação de azeite de oliva (rico em ômega-9) por gavagem por sete dias e o grupo estudo recebeu ômega-3 em forma de emulsão isocalórica e isovolumétrica, também por gavagem, na dose de $100 \mathrm{mg} /$ $\mathrm{kg} /$ dia por sete dias no pré-operatório. Ambos os grupos foram submetidos à duas colotomias seguidas de anastomose colônica, em cólon direito e cólon esquerdo, respectivamente. Foram avaliados a evolução do peso dos animais, morbimortalidade e realizados testes tensiométrico e de densitometria do colágeno dos corpos de prova. Resultados: Não houve diferenças na evolução do peso e na morbimortalidade entre os grupos. O valor da força de tração máxima do grupo controle foi de $1,9 \pm 0,3 \mathrm{~N}$ e no grupo estudo de $1,7 \pm 0,2, p=0,357$. Houve, no entanto, maior quantidade de colágeno tipo I $(p=0,0126)$ na anastomose no grupo estudo. $O$ índice de

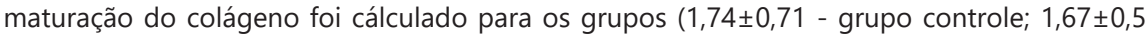
- grupo estudo, $p=0,719)$. Conclusões: A suplementação pré-operatória com ácido graxo ômega-3 está associada ao aumento da deposição de colágeno do tipo I em anastomoses de cólon em ratos no $5^{\circ}$ dia do pós-operatório, mas não exerce influência na resistência tênsil de colorrafia ou no índice de maturação do colágeno.

mmunonutrition is defined as the use of specific nutrients in formulas which promote through different mechanisms of action, effects on the inflammatory and imune systems $\mathrm{s}^{4,10,14,22}$.

Initially tested in animal models, these formulas were started to be used in patients previously malnourished that were to be submitted to surgical procedures. Clear benefits were obtained on postoperative recovery, with reduced morbidity rate, length of hospital stay and duration of mechanical ventilation in intensive care units $^{21}$. However, the use of these formulas has spread and studies began to show positive effect also in well-nourished individuals s, 15,23,24,25,26. $^{\text {. }}$ 
However, due to the complex mechanism of interaction between absorption processes, membranes attachment and intracellular signaling, it is known that formulas consisting of amino acids, essential fatty acids, trace elements, vitamins, nucleotides and nucleosides, were effective when using together, while the use of specific nutrients alone was associated with less clear benefits and with divergent results ${ }^{5}$.

The use of long-chain polyunsaturated fatty acids have been studied in the context of healing and tissue regeneration, mainly due to its anti-inflammatory, immunoregulatory and antioncogenics properties. However, studies performed in rat models of induced colitis resulted in negative results, in which the use of omega-3 was detrimental, resulting in deterioration of colitis $^{16,29}$.

Its anti-inflammatory properties arise from processes such as the partial replacement of arachidonic acid in cell membranes, and thus, a reduction in the production of derivatives considered pro-inflammatory, such as prostaglandin E2. There is also a reduction in the chemotaxis of monocytes and neutrophils, modulating the inflammatory response in its earliest stages. Also notable are its immunoregulatory effects by reducing the proliferation of cytotoxic T lymphocytes in response to proinflammatory cytokines, the production of mediators such as nitric oxide and tumor necrosis factor 1,2,13,28.

Thus, despite the fact that omega- 3 fatty acids play a clear role in the inflammatory response, the supplementation with omega- 3 and its role in the overall context of colonic anastomosis healing is still unknown ${ }^{4}$.

The aim of this study was to evaluate the influence of preoperative supplementation with omega- 3 fatty acids on the healing of colonic anastomoses in rats.

\section{METHODS}

Forty Wistar adult male rats (Rattus norvegicus albinus, Rodentia mammalia), weighing $234.4 \pm 22.3 \mathrm{~g}$ obtained from the Universidade Estadual de Maringá were acclimatized individually receiving ad libitum standard rat chow prior to the surgical procedure. Seven days before surgery, the control group (GAO) received daily olive oil supplementation while the study group (GOM), received omega-3 fatty acid emulsion as an isocaloric and isovolumetric emulsions at a dose of $100 \mathrm{mg} / \mathrm{kg} /$ day through an rigid orogastric tube.

Both groups received the fatty acids suplementation through an orogastric gavage without anesthesia and were submitted to two colotomies followed by anastomosis with interrupted 6-0 nylon in the right and left colon, respectively. On the $5^{\text {th }}$ postoperative day, rats were killed. Parameters evaluated included changes in body weight, anastomotic complications and mortality, as well as maximum tensile strength by using a tensiometer and collagen densitometry at the anastomotic site. Statistical analysis was performed using the Student t test, Mann-Whitney test, Fisher's exact test and Z-test to compare proportions, with $p<0.05$.

RESULTS

Anastomotic leakages occurred in four animals in each group. The mortality rate in the GAO group was $35.0 \%(n=7)$ and $10.0 \%(n=2)$ in the GOM group, $p=0.1973$. There were no diferences in the average weight at the beginning of the experiment, on the $7^{\text {th }}, 14^{\text {th }}, 21^{\text {st }}$ day, the day of surgery and the day of sacrifice, respectively (Table 1).
TABLE 1 - Average weight \pm standard error (SE) per group (g)

\begin{tabular}{|c|c|c|c|c|c|c|c|c|}
\multirow{2}{*}{ Days } & \multicolumn{3}{|c|}{ GAO $(n=20)$} & \multicolumn{3}{c|}{ GOM $(n=20)$} & p \\
\cline { 2 - 8 } & Average & \pm & SE & Average & \pm & SE & \\
\hline D0 & 292,3 & \pm & 4,4 & 284,3 & \pm & 5,3 & 0,343 \\
\hline D7 & 322,3 & \pm & 5,0 & 313,1 & \pm & 5,6 & 0,208 \\
\hline D14 & 348,4 & \pm & 5,5 & 339,0 & \pm & 6,5 & 0,323 \\
\hline D21 & 369,7 & \pm & 6,2 & 363,4 & \pm & 6,9 & 0,695 \\
\hline DCx & 349,7 & \pm & 6,4 & 344,0 & \pm & 7,2 & 0,561 \\
\hline DSx & 321,0 & \pm & 8,8 & 316,1 & \pm & 3,8 & 0,857 \\
\hline
\end{tabular}

$D 0=$ first day of study; $D C x=$ day of surgery; $D S x=$ day of sacrifice; $G O M=$ omega-3 group; $\mathrm{GAO}=$ olive oil group; $\mathrm{p}=$ statistical signicance (Mann-Whitney test)

The value of the maximum tensile strength of the GAO group was $1.9 \pm 0.3 \mathrm{~N}$ and the GOM group $1.7 \pm 0.2, \mathrm{p}=0.357$ (Figure 1). The rupture force of groups GAO and GOM were also similar $(1,5+0,2$ vs $1,4+0,2$ respectively, $p=0,3572)$.

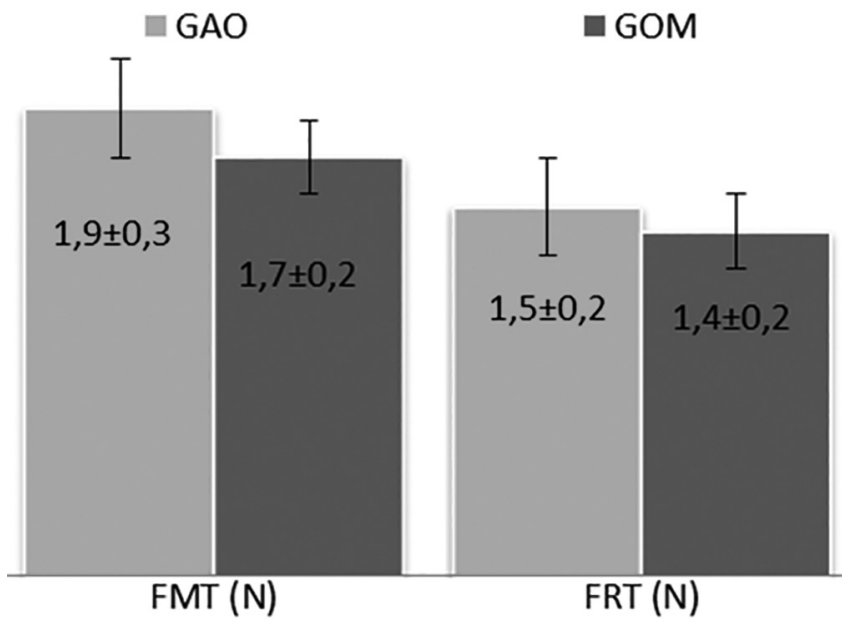

$p=$ statistical significance; $F M T=$ maximum strenght rupture force $(p=0,6028) ; F R T=$ total rupture force $(p=0,3572) ; N=$ newtons; $G A O=$ olive oil group; $G O M=$ omega-3 group (Mann-Whitney test)

FIGURE 1-Comparison between maximum tensile strength of the GAO and GOM groups

There was, however, a larger amount of type I collagen deposition ( $p=0.0126$ ) in the GOM group (Figure 2 ).

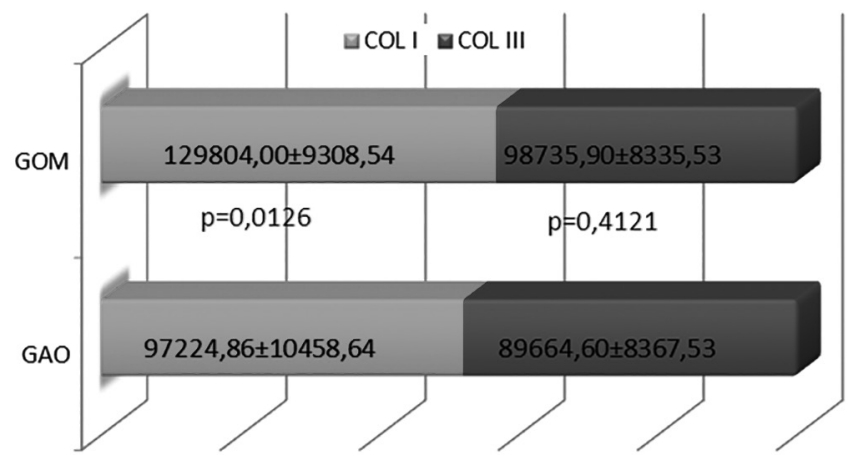

$\mathrm{COL}$ I=type I collagen; $\mathrm{COL}$ III =type III collagen; $\mathrm{GAO}=$ olive oil group; $\mathrm{GOM}=$ omega-3 group; SEM=standard error; $p=$ statistical significance

FIGURE 2 - Type I and III collagen distribuition among GOM and GAO groups

The collagen maturation index $(\mathrm{CMI})$ at the anastomotic site was calculated for both groups (GAO - 1.74 \pm 0.71 ; GOM $1.67 \pm 0.5 ; p=0,719)$ and no difference were detected (Table 2 ). 
TABLE 2 - Average \pm standard error for collagen maturation index for $\mathrm{GAO}$ and $\mathrm{GOM}$ groups

\begin{tabular}{|c|c|c|c|c|c|}
\hline \multirow{2}{*}{ Groups } & \multicolumn{4}{|c|}{ CMI } & \multirow{2}{*}{$p$} \\
\hline & $n$ & Média & \pm & EP & \\
\hline GAO & 13 & 1,74 & \pm & 0,71 & \multirow{2}{*}{0,719} \\
\hline GOM & 18 & 1,67 & \pm & 0,5 & \\
\hline
\end{tabular}

$\mathrm{CMI}=$ collagen maturation index; $\mathrm{GAO}=$ olive oil group; $\mathrm{GOM}=$ omega-3 group $\mathrm{SEM}=$ standard error; $\mathrm{p}=$ statistical significance (Mann-Whitney test)

\section{DISCUSSION}

The wound healing of the intestine after an anastomosis depends on balanced reconstitution, proliferation and differentiation processes.

The intestinal cells can be injured by surgery, inflammatory diseases, or toxic luminal substances, despite of its barrier function. The healing process starts with de surrounding epithelial cells that loses their columnar polarity, becoming a flattered cell that migrates into the denude area to restore the intestinal barrier ${ }^{12}$ and despite where the healing process is located, the phases of healing tends to occur in a certain sequence: inflammatory, proliferation and maturation. Each phase has its own particular duration and cell-type envolved.

Cellular types such as neutrophils, macrophages, fibroblasts and even platelets play a fundamental role through secretion of chemoatrative factors, cell-to-cell interations and are vunerable to a vaste type of interferences, promoted mostly by the nutritional status of the host, presence or not of inflammatory process and oxidative stress. In this case the primary proinflammatory cytokines such interleukin-1 (IL-1), IL-6 and tumor necrosis factor- $\alpha$ (TNF- $\alpha$ ) and also the autocrine, paracrine and endocrine events can be affect by such factors ${ }^{17}$.

All these interations of proinflammatory cytokines assist in controlling infection and prepare tissue for repair by promoting and enhacing phagocytic activity, stimulating keratinocyte migration, fibroblast chemotaxis and by regulating the remodulation of the extracellular matrix proteins ${ }^{12,17}$.

In this scenario, the role of immunonutrition on the colonic anastomotic healing depends on physiological performance and specific molecular interactions of the nutrients involved. Both macro and micronutrients with immuno-modulating activities have been identified, and the rationale for the use of such formulations in surgical patients is the need to reduce or mitigate the inflammatory response at specific times during surgical recovery 22 .

Inflammation is part of the healing process. The omega-9 olive oil was chosen as a isocaloric control because of its neutral activity as inflammation is concerned. The use of the more usual soybean oil, presented in most lipid emulsions, could result in an stimulation of the inflammatory process due to its rich content of linoleic acid, a pro-inflammatory precursor.

Many studies have shown clear benefit of the use of immune- modulating enteral formulas by various mechanisms, because they enhancing the immune status in its various aspects ${ }^{11}$. However, the use of individual components present in these formulas did not bring such positive evidences and literature is divergent as regards to its results ${ }^{4,5}$. The omega- 3 polyunsaturated fatty acids have been shown to play an important role in the mechanisms involving cellular signaling pathways that culminate with an anti-inflammatory effect. For example, they reduce TNF- $\alpha$ production by macrophages, as well as the production of pro-inflammatory cytokines and nitric oxide e $^{1,7,9,18}$.

The immune response ability to generate an inflammatory response is eventually modified by the addition of omega- 3 polyunsaturated fatty acids in the diet. The cell membrane modifies its characteristics, showing better fluidity, lipid domain areas, and a greater or lesser affinity for certain pathways which ultimately modulates especially leukocyte function. As a result, there is a competition for the same enzymatic pathways as arachidonic acid (AA), but generating less inflammatory eicosanoids. It also reduces the ability of macrophages to present antigens $\mathbf{s}^{1,3,6,13,17,20,27,30}$. One possible consequence of the administration of omega- 3 fatty acids would be the reduction of the healing process, particularly in the breaking strength, because it attenuates the inflammatory phase of the healing process. Therefore our finding that the administration of omega-3 did not reduce the tensile strength is remarcable.

The omega- 3 can act also by competing with LTB4 receptors occupancy, blocking the transduction signals for synthesis of core protein $\mathrm{G}$, or even in cell signaling through inhibition of phospholipase $\mathrm{C}$ activation induced by TNF- $\alpha$, hampering or delaying the cellular signs 1,27,30.

This network involving pro and antiinflamatory factors among a nutricional status and exogenous administration of omega-3 fatty acids affects the balance of intestinal healing process in its various aspects that are still object of study by many researchers throughout the world.

\section{CONCLUSIONS}

Preoperative supplementation with omega-3 is associated with increased collagen deposition of type I fibers in colonic anastomoses in rats on the $5^{\text {th }}$ postoperative day. No differences were observed in the breaking strength or collagen maturation index.

\section{REFERENCES}

1. Calder PC. Immunoregulatory and anti-inflammatory effects of $n-3$ polyunsaturated fatty acids. Braz J Med Biol Res. 1998 Apr; 31(4): 467-490. doi: 10.1590/S0100-879X1998000400002.

2. Calder PC. Polyunsaturated fatty acids, inflammation, and immunity. Lipids.2001Sep; 36(9): 1007-1024. doi: 10.1007/s11745-001-0812-7.

3. Calder PC. Polyunsaturated fatty acids, inflammatory process and inflammatory bowel diseases. Mol Nutr Food Res. 2008 May; 52(8):885-897. doi: 10.1002/mnfr.200700289.

4. Chow $O$, Barbul A. Immunonutrition: Role in Wound Healing and Tissue Regeneration. Advances in Wound Care. 2014 Jan; 3(1):46-48. doi: 10.1089/wound.2012.0415.

5. Corrêa-Neto MP, Campos ACL, Branco AB, Matias JEF. Efeito da suplementação dietética de arginina na cicatrização das anastomoses colônicas em ratos. ABCD Arq Bras Cir Dig. 2009 Nov; 22(1):7-14. PMID: 559771.

6. Eisner F, Jacob P, Frick JS, Feilitzsch M. Immunonutrition with longchain fatty acids prevents activation of macrophages in the gut wall. J Gastrointest Surg. 2011 Mar; 15(5): 853-859. doi: 10.1007/ s11605-011-1431-z

7. Endres S, Reza Ghorbani BS, Kelley VE, Georgilis K, Lonnemann G, Van Der Meer JWM. The Effect of Dietary Supplementation with n-3 Polyunsaturated Fatty Acids on the Synthesis of Interleukin-1 and Tumor Necrosis Factor by Mononuclear Cells. N Engl J Med. 1989 Feb; 320(5): 265-271. doi: 10.1056/NEJM198902023200501.

8. Flesch AG, Poziomyck AK, Damin DC. The therapeutic use of symbiotics. Arq Bras Cir Dig. 2014 Jul-Sep;27(3):206-9.

9. Grimm H, Mayer K, Mayser P, Eigenbrodt E. Regulatory potential of $n-3$ fatty acids in immunological and inflammatory processes. British Journal of Nutrition. 2002 Mar; 87(Suppl.1): S59-S67. doi: 10.1079/BJN2001457.

10. Guimarães MV, Moreira GH, Rocha LP, Nicoluzzi JE, de Souza CJ, Repka JC. L-arginine action in cutaneous flap evolution under nicotine exposure in rats. Rev Col Bras Cir. 2013 Jan-Feb;40(1):49-54.

11. HeysSD, WalkerLG, SmithI, ErminO. Enteral nutritional supplementation with key nutrients in patients with critical illness and cancer: a meta-analysis of randomized controlled clinical trials. Ann Surg. 1999 Apr; 229(4): 467-477. PMID: 1191731.

12. lizuka M, Konno, S. Wound healing of intestinal epithelial cells. World J Gastroenterol. 2011 May; 17(7): 2161-2171. doi: 10.3748/ wjg.v17.i17.2161 
13. Kuratko CN. Proliferation of colonic lymphocytes in response to inflammatory cytokines is lower in mice fed with fish oil than in mice fed with corn oil. Cancer Lett. 2000 Jan; 148(1):27-32. doi: 10.1016/S0304-3835(99)00266-9.

14. Magalhães CR, Malafaia O, Torres OJ, Moreira LB, TefilSC, Pinherio Mda $\mathrm{R}$, Harada BA. Liver regeneration with I-glutamine supplemented diet: experimental study in rats. RevColBras Cir.2014Mar-Apr;41(2):117-21.

15. Marimuthu K, Varadhan K, Ljungqvist O, Lobo D. A Meta-Analysis of the Effect of Combinations Of Immune Modulating Nutrients on Outcome in Patients Undergoing Major Open Gastrointestinal Surgery. Annals OfSurgery.2012 Jun;6(255):1060-1068. doi:10.1097/ SLA.0b013e318252edf8.

16. Matsunaga $\mathrm{H}$, Hokari R, Kurihara C, Okada Y, Takebayashi K, Okudaira K, Watanabe C, Komoto S, Nakamura M, Tsuzuki Y, Kawaguchi A, Nagao S, Itoh K, Miura S. Omega-3 fatty acids exacerbates DSSinduced colitis through decreased adiponectin in colonic subepithelial myofibroblasts. Inflamm Bowel Dis. 2008 May; 10(14):1348-1357. doi: 10.1002/ibd.20491.

17. McDaniel JC, Belury M, Ahijevych K, Blakely W. w-3 fatty acids effect on wound healing. Wound Repair Regen. 2008 May-June; 16(3): 337-345. doi: 10.1111/j.1524-475X.2008.00388.x

18. Novak TE, Babcock TA, Jho DH, Helton WS, Espat NJ. NF-kappa $B$ inhibition by omega-3 fatty acids modulates LPS-stimulated macrophage TNF-alphatranscription. Am J Physiol Lung Cell Physiol. 2003 Jan; 284(1): L84. doi: 10.1152/ajplung.00077.2002.

19. PaschoalVA, VinoloMA, CrismaAR, MagdalonJ, CuriR. Eicosapentaenoic (EPA) and docosahexaenoic (DHA) acid differentially modulate rat neutrophil function in vitro. Lipids. 2013 Feb; 48(2): 93-103. doi: 10.1007/s11745-012-3726-6.

20. Sherrington EJ, Sanderson P, Calder PC. The effect of dietary lipid manipulation on macrophage cell surface molecule expression. Biochemical Society Transactions. 1995 May; 23(2): 272S. PMID: 7672298.

21. Silveira TM, Sousa JB, Stringhini ML, Freitas AT, Melo PG. Nutritional assessment and hand grip strength of candidates for surgery of the gastrointestinal tract. Arq Bras Cir Dig. 2014 Apr-Jun;27(2):104-8.

22. SuchnerU; Kuhn KS; FürstP. The scientific basis ofimmunonutrition. Proc NutrSoc. 2000 Nov; 59 (4):553-563. doi:10.1017/S0029665100000793.

23. Thieme RD, Cutchma G, Chieferdecker ME, Campos AC. Nutritional risk index is predictor of postoperative complications in operations of digestive system or abdominal wall? Arq Bras Cir Dig. 2013 NovDec;26(4):286-92.

24. Turnock A, Calder PC, West AL, Izzard M, Morton RP, Plank LD. Perioperative Immunonutrition in Well-Nourished Patients Undergoing Surgery for Head and Neck Cancer: Evaluation of Inflammatory and Immunologic Outcomes. Nutrients. 2013 Apr; 5(4):1186-1199. doi: 10.3390/nu5041186.

25. Waitzberg DL, Torrinhas RS. Fish oil lipid emulsions and immune response: what clinicians need to know. Nutr Clin Pract. 2009 AugSept; 24(4):487-499. doi: 10.1177/0884533609339071.

26. Weimann A, Braga M, Harsanyi L, Laviano A, Ljungvist O, Soeters $\mathrm{P}$, Kemen JM, Hiesmayr JM, Horbach T, Kuse ER, Vestweber KH. ESPEN Guidelines on Enteral Nutrition: Surgery including Organ Transplantation. Clinical Nutrition. 2006 Apr; 25(2): 224-244. doi:10.1016/j.clnu.2006.01.015.

27. Werner S, Grose R. Regulation of Wound Healing by Growth Factors and Cytokines. Physiol Rev.2003 July; 83(3):835-870. PMID: 12843410
28. Whiting CV, Bland PW, Tarlton JF. Dietary n-3 polyunsaturated fatty acids reduce disease and colonic proinflamamtory cytokines in a mouse model for colitis. Inflamm Bowel Dis. 2005 Apr; 11(4): 340 349. doi: 10.1097/01.MIB.0000164016.98913.7c.

29. Woodwoth HL, McCaskey SJ, Duriancik DM, Clinthorne JF, Langohr IM, Gardner EM, Fenton Jl. Dietary fish oil alters T lymphocyte cell populations and exacerbates disease in a mouse model inflammatory colitis. Cancer Res. 2010 Oct; 20(70): 7960-7969. doi: 10.1158/00085472.

30. Yagaloff KA, Franco L, Simko B, Burghardt B. Essential fatty acids are antogonists of the leukotriene B4 receptor. Prostaglandins, Leukotrienes and Essencial Fatty Acids. 1995 May; 52(5): 293-297. doi: 10.1016/0952-3278(95)90029-2. 